\title{
Artistic feasibility research on a standalone hybrid solar/wind system based on IncCond algorithm under variable load demands-a case study: South Algeria
}

\author{
Oumelkhier Bouchiba, Tahar Merizgui, Bachir Gaoui, Saliha Chettih, Ali Cheknane \\ Semiconductors and Functional Materials Laboratory, University of Laghouat, Laghouat, Algeria
}

\section{Article Info}

Article history:

Received Nov 9, 2020

Revised May 4, 2021

Accepted May 17, 2021

\section{Keywords:}

Maximum power point tracker

Performance

Photovoltaic

Wind energy

\begin{abstract}
The aim of this research study is to describe the hybrid renewable energy resources, the photovoltaic and the wind turbine are utilized to produce AC power for a Sahara Hassi R'Mel region in south of Algeria is optimally designed. Hybrid power generation systems are an operative solution for the variable generated power of renewable energy sources. In the new design, the ability circuit and the surveillance regulation of the presented grid-connected hybrid power system simulation is examined via MATLAB/Simulink. To detect the feasibility of the controlled system, this system is studied under various solar radiation and wind speed profiles. On the basis of the results, good tracking with a high accuracy rate is obtained after using filtering component by enhancing the different topology configurations in the expression of comparison voltage $(\mathrm{V})$, and power (W). Overtime, the overall system efficiency is enhanced compared to the MPPT control system. The obtained simulation results for the incremental conductance PV/Wind MPPT controller have accomplished high effective system achievements. IncCond method is appropriate for working in vastly variable weather conditions with easy design, high tracking velocity, and minimum step count.
\end{abstract}

This is an open access article under the CC BY-SA license.

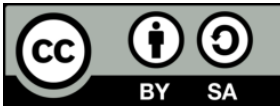

\section{Corresponding Author:}

Tahar Merizgui

Department of Electronic, Amar Telidji University

University of Laghouat

B.P. 37G, Laghouat 03000, Algeria

Email: t.merizgui@lagh-univ.dz

\section{INTRODUCTION}

Due to the stochastic behavior of both PV and wind turbine, the large parts in the designing of the hybrid power system are the credible energy feeding of the consumer under changing atmospheric conditions and the cost of the $\mathrm{kWh}$ of power [1]-[3]. Renewable energy sources have received major observation through the bygone few decades and big efforts have been made to improve an efficient renewable energy processing system. The greater thematic of these oncoming are to have diminutive environmental damage, keeping of power, and it could be utilized in equipping energy either directly to a utility grid or to an isolated area (stand-alone systems) [4], [5]. By the central inverter topology that purposes that photovoltaic (PV) modules are linked at single mutual range both in series and parallel which is linked to single big inverter, which performed through MPPT control. This topology has frugal helps accordingly the quantity of the inverters is low; however, the part-time shadowing of the single PV panel will impact on the entire array energy output. The major advantages of the centralized inverter are the plainest of the layout, easy maintenance and control that lead to low cost. Assortment of MPPT techniques is used in wind turbines to adjust the generator speed through the optimal speed [6], [7]. 
Voyant et al. [8] present the fundamental object for outlook world power feeding and request will be the rise renewable energy integration resources to the future energy demand outfit connections. Although, the wind energy purpose yet faces many obstacles, it is a volatile saving of power to the electricity networks and it is locative and interim variable given by Gnana [9]. A megawatt of intensified solar energy incorporated in 2017 by Sangster, [10], for 2017, overall 353.5 TWh of wind power usage and 113.9 TWh of photovoltaic usage were produced in Europe. (Lauret) applies renewable energy forecast to predict the obtainable generation ability of renewable power sources in the near outlook [11]. The renewable energy forecast could be categorized at two denominations: indirect prediction denominations and direct forecast approximations. In order to enhance the achievement of the PV/Wind systems and to extract the MPP under changing weather condition is needful to track the MPP using control technique irrespective of load variation. In the literature, several MPPT methods have been suggested depends on different factor like the dynamic of speed of wind and irradiance, the cost, and the design simplicity [12]-[15]. Hegazy and Eltamaly [16] provide a complete analysis of different of MPPT techniques used in solar panel system. The common tracking techniques founded at this process are exceedingly adopted on PV systems, which contain but not limited to, perturb, and observe technique $(\mathrm{P} \& \mathrm{O})$, and the incremental conductance technique (IncCond) [17].

The objective of this work is to investigate goodness of proposed the smart design, dynamic performance, and control of the hybrid renewable power system. The maximum power point tracking (MPPT) is applied in the control installation both by generator wind/PV systems. Therefore, an efficient implementation of MPPT control to reinforce output power in grid-connected photovoltaic and wind turbine system is presented. In accordance with developing an acceptable model of the proposed power generation system under characterization analytic solutions, a decoupling control for power generation via MPPT control algorithm is obtained. These luxuriously enhance the hybrid design of PV/Wind connected grid system quality. The system connected with the utility power is fundamentally collected of photovoltaic and wind power generation systems and three-phase grid. The configuration of the smart suggested gridconnected PV/Wind generator systems is presented in Figure 1.

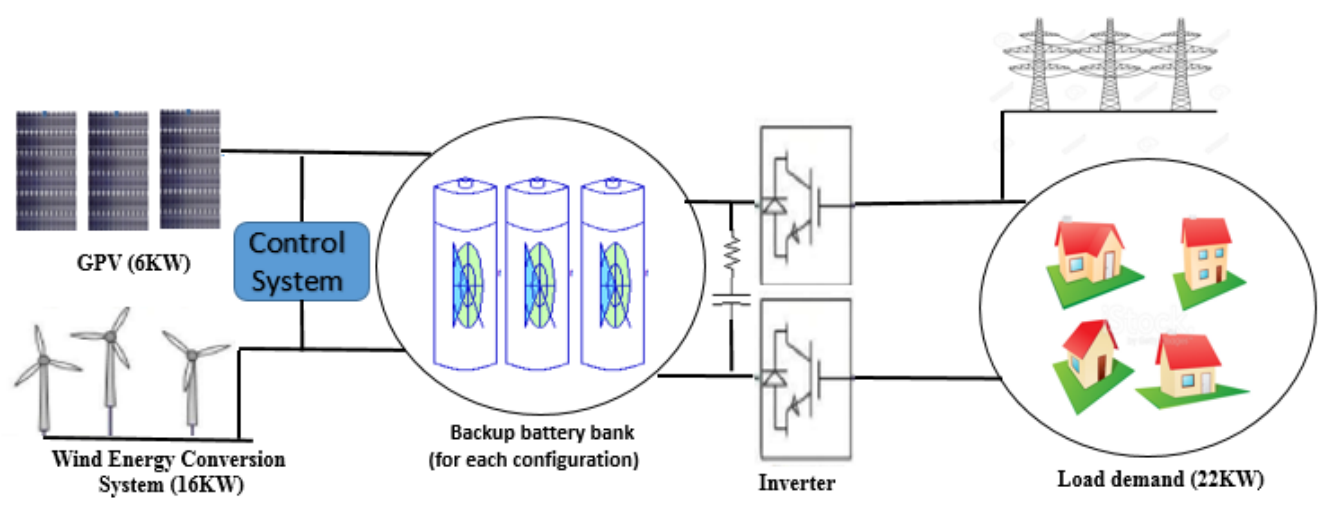

Figure 1. Configuration of the intelligent proposed grid-connected PV/Wind generator systems

\section{HYBRID SYSTEM}

\subsection{Photovoltaic array modelling}

Figure 2 explains the equivalent example of PV cell in which a cell photo current is paralleled at a diode and there is the intrinsic shunt and series resistors, $\mathrm{R}_{\mathrm{Sh}}$ [18]. The main model for the theoretical of semiconductors that mathematically characterize the I-V of the PV cells as in (1), (2).

$$
\begin{aligned}
& I=I_{P V . c e l l}-\frac{I_{0 . c e l l}\left[\exp \left(\frac{q V}{\alpha K T}\right)-1\right]}{I_{d}} \\
& I_{d}=I_{0 \text { cell }}\left\{\exp \left[\frac{q V}{A} \cdot k T\right]-1\right\}
\end{aligned}
$$

Where, $I_{d}=$ diode current $(A), I_{P V}$,cell $=$ the current created through coming light $(A) . I_{0, \text { cell }}=$ the reverse saturation of the diode $(\mathrm{A})$.

Solar modules are composed from a several linked PV array and the control of the properties at the terminals of the practical organize demand the inclusion of extra condition of the basic form: 


$$
\begin{aligned}
& I=I_{p v}-I_{0}\left[\exp \left(\frac{V+R_{S} I}{\alpha V_{t}}\right)-1\right]-\frac{V+R_{S} I}{R_{p}} \\
& I_{p v}=\left(I_{p v, n}+k_{I} \Delta_{T}\right) \frac{G}{G_{n}}
\end{aligned}
$$

with IPV present the photovoltaic current and $I_{0}$ is the saturation current of the solar cell. Vt=Ns.k.T/q is the thermal voltage of the solar cell. Ns present the connected of cells in series. $\mathrm{R}_{\mathrm{S}}$ present the series resistance of the solar cell and $R_{P}$ is the parallel resistance. $G n$ and $G$ represent the light created current on the nominal case (in STP $25^{\circ} \mathrm{C}$ and $1000 \mathrm{~W} / \mathrm{m}^{2}$ ). $\Delta \mathrm{T}=\mathrm{T}-\mathrm{Tn}, \mathrm{T}$ is real temperature $(\mathrm{K})$ and $\mathrm{Tn}$ represent the nominal temperatures $(\mathrm{K})$. $\mathrm{G}$ is solar irradiation at the system area $\left(\mathrm{W} / \mathrm{m}^{2}\right)$, and $\mathrm{Gn}$ represents the nominal irradiation $\left(\mathrm{W} / \mathrm{m}^{2}\right)$. The diode saturation current Io and its reliance on the temperature are described as:

$$
\begin{aligned}
& I_{0}=I_{0, n}\left(\frac{T_{n}}{T}\right)^{3} \exp \left[\frac{q E_{g}}{\alpha K}\left(\frac{1}{T_{n}}-\frac{1}{T}\right)\right] \\
& I_{o, n}=\frac{I_{s c, n}}{\exp \left(\frac{V_{o c, n}}{\alpha V_{t, n}}\right)-1} \\
& I_{0}=\frac{I_{s c, n}+K_{I} \Delta_{T}}{\exp \left(\frac{V_{s c, n}+K_{v} \Delta_{T}}{\alpha V_{t}}\right)}
\end{aligned}
$$

The $\mathrm{V}_{\mathrm{t}, \mathrm{n}}$ represent the thermic energy voltage of the Ns series associated PV cells at the nominal temperature $\mathrm{Tn}$. Where $\mathrm{K}_{\mathrm{V}}$ and $\mathrm{K}_{\mathrm{I}}$ appear the energy current and voltage coefficients, respectively.

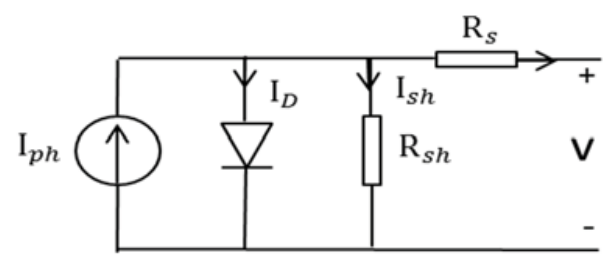

Figure 2. The equivalent circuit of a classical PV cell

\subsubsection{Characteristic of PV array model}

Through examining $25^{\circ} \mathrm{C}$ and $1000 \mathrm{~W} / \mathrm{m}^{2}$ as the linkage situations of $\mathrm{PV}$, the characteristic curves for I$\mathrm{V}$ and P-V of the studied PV cell with a variation of irradiation/temperature range and series/parallel, connections of PV panels are prerequisite in this study as shown in Figures 3(a) to 3(d). Thus, PV panels are linked in series/parallel and form generator solar PV, which are eligible to increase in tension and current, generations.

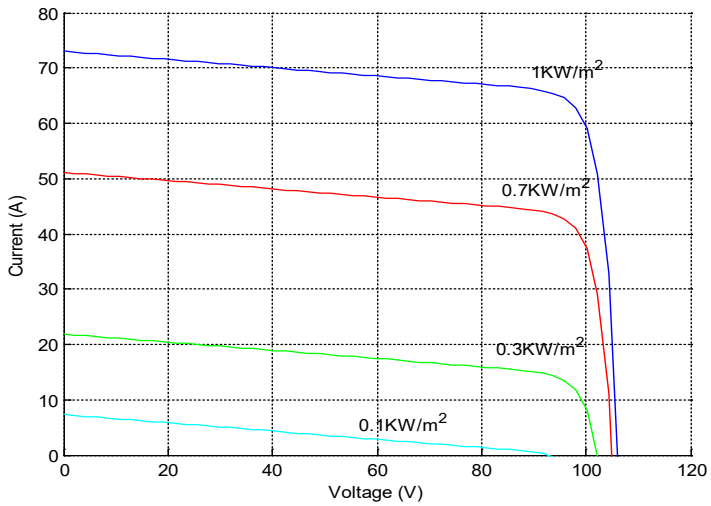

(a)

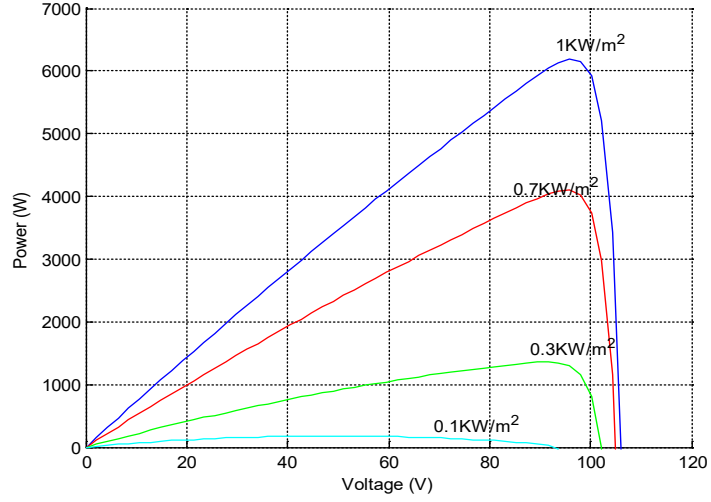

(b)

Figure 3. Characteristic of PV array model; (a-d) simulated P-V and I-V curve for various irradiance/temperature level and series/parallel connection, respectively 


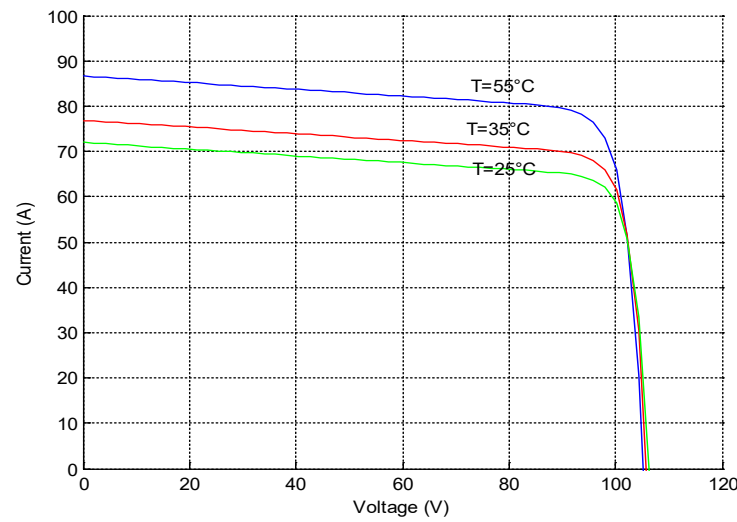

(c)

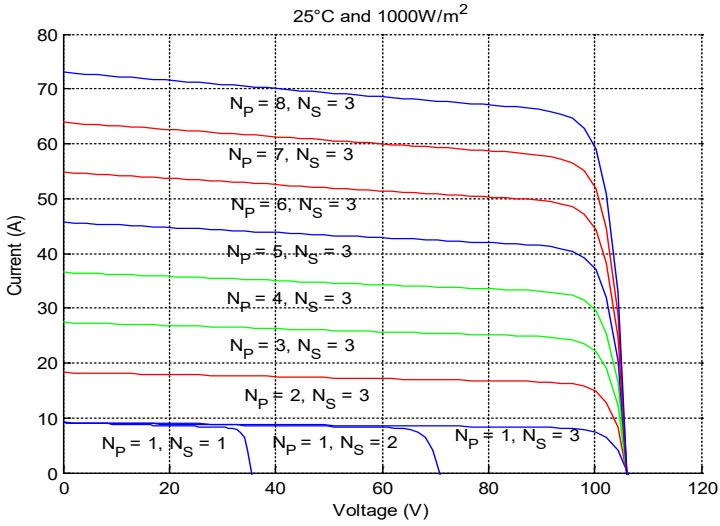

(d)

Figure 3. Characteristic of PV array model; (a-d) simulated P-V and I-V curve for various irradiance/temperature level and series/parallel connection, respectively (Continue)

\subsection{Wind generator system}

The wind turbine WT transforms wind power to mechanical power through means of a torque exercised to a drive chain [19], [20]. The torque T and energy generated via the wind turbine at the interval $\mathrm{V}_{\min }$ present the minimum of wind speed. $\mathrm{V}_{\max }$ present the maximum of wind speed are functions of the wind turbine blade air pressure for performance and controlled set up as shown in Figure 4(a), radius R, coefficients of power $C_{P}$ and $C_{q}$ and $V_{\text {wind }}$ wind speed [21]-[25].

$$
P_{m}=C_{p}(\lambda, \beta) \frac{\rho A}{2} V_{\text {wind }}^{3}
$$

Where $C_{P}$ represents the energy coefficient and describes the capability of the wind turbine to produce power from the wind system. Cq is known the torque factor and is linked to according to:

$$
C_{q}=\frac{C_{P}}{\lambda} ; \lambda=\frac{R \cdot \omega}{V_{\text {wind }}} ; T=\frac{P_{m}}{\omega}
$$

with,

$C_{\mathrm{P}}=$ Coefficient of power, $\mathrm{P}_{\mathrm{m}}=$ Mechanical output energy, $\beta=$ Blade pitch angle.

$\rho=$ Air density $\left(\mathrm{kg} / \mathrm{m}^{3}\right), \mathrm{V}_{\text {wind }}=$ Wind speed $(\mathrm{m} / \mathrm{s}), \mathrm{A}=$ Turbine space $\mathrm{m}^{2}$.

$\lambda=$ is the tip velocity ratio, $\mathrm{R}=$ Radius of turbine area $(\mathrm{m}), \mathrm{T}=$ represent the torque of WT system,

$\omega=$ Angular frequency of rotary turbine ( $\mathrm{rad} / \mathrm{sec})$.

The performance factor $\mathrm{Cp}(\lambda, \beta)$, which pertains by speed ratio $\lambda$ and pitch angle $\beta$ as shown in Figure 4(b), defines how considerably of the wind active power could be apprehended via the WT system. A nonlinear model characterizes $\mathrm{Cp}(\lambda, \beta)$ as:

$$
C_{P}(\lambda, \beta)=C_{1}\left(\frac{C_{2}}{\lambda_{I}}-C_{3} \beta+C_{4}\right) e_{\lambda i}^{-C 5}+C_{6}
$$

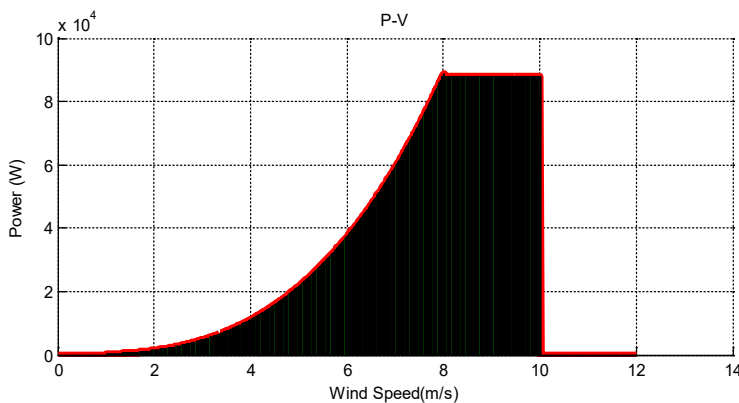

(a)

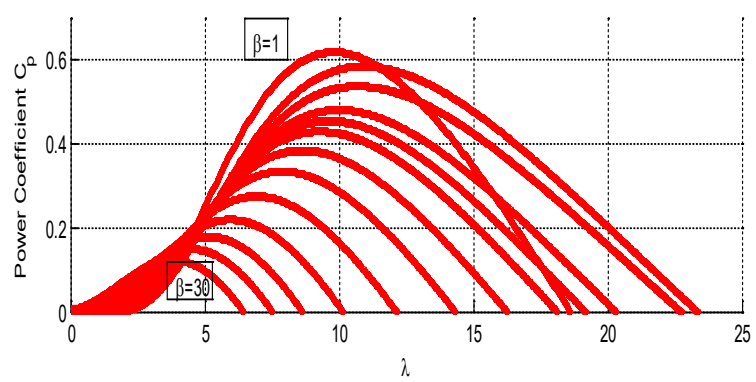

(b)

Figure 4. Wind generator system; (a) the performance and controlled set up of wind turbine speed, (b) the performance coefficient $\mathrm{Cp}(\lambda, \beta)$, which depends on speed ratio $\lambda$ and blade pitch angle $\beta$ 


\subsubsection{Sites presentation}

The wind power forecast is specific as a fundamental instrument to give the system engineers with considerable evaluation of accessible wind energy information in future period. This type of appreciation is repeatedly applied in power scheduling and resource balancing by [26]. The solar power could be predicted in the long-term by latest technologies like ground based atmosphere imaging as show in the following figure of the Hassi R'Mel region. Laghouat (Hassi R'mel) is the largest industrial city in center Algeria, which is located at the beginning of the Sahara Desert at Algeria. Hassi R'Mel featured by the high wind speed compared to the other cities in Algeria. Figures 5-7 present the wind speed measurement of April, August, September, and November in three years, respectively, by weather stations in Laghouat province. Figure 8, present the global value measurement of monthly incident radiation on a horizontal plane in five years from 2013 to 2017.

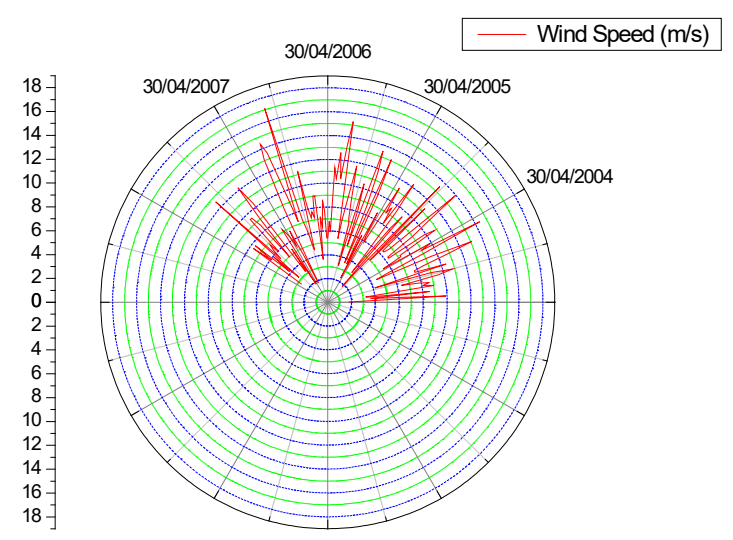

Figure 5. Wind speed measurement of April in three years (Hassi R'mel, Laghouat)

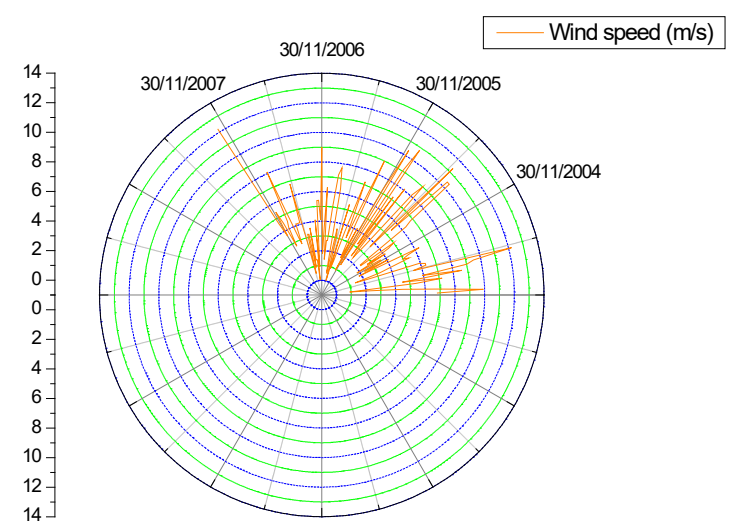

Figure 7. Wind speed measurement of November in three years (Hassi R'mel, Laghouat)

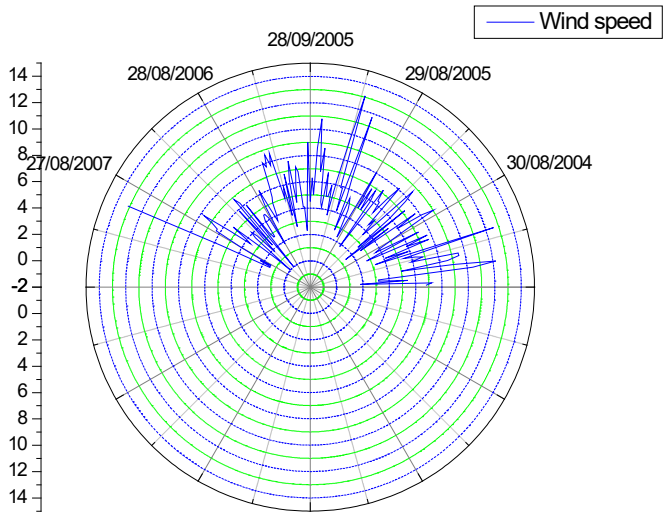

Figure 6. Wind speed measurement of August/September in three years (Hassi R'mel, Laghouat)

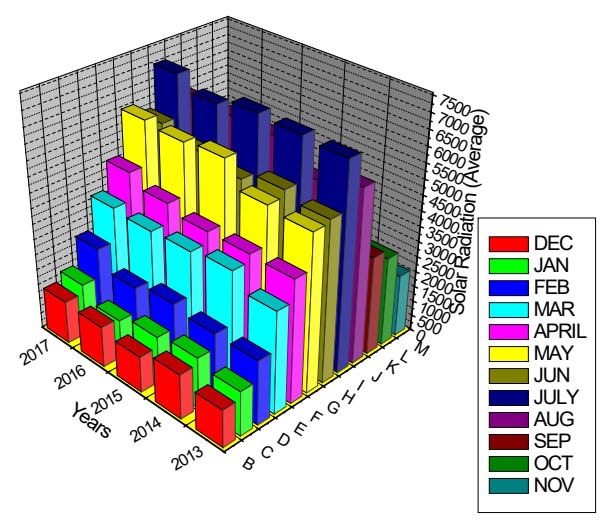

Figure 8 . Global values of monthly incident radiation on a horizontal plane at five years in $\left[\mathrm{Wh} / \mathrm{m}^{2} / \mathrm{j}\right]$

\subsection{Control algorithm}

A solar PV and WT generators, whose are linked with a DC/DC converter to inject both of hybrid power generate to the load. Figure 9 explain the MPPT controller flowchart for PV and Wind turbine system. By following step, the reference voltage should be changed as much as dc differences $(\Delta \mathrm{V})$. Thereafter, if $\mathrm{P}(\mathrm{k})>\mathrm{P}(\mathrm{k}-1)$, the equal of $\Delta \mathrm{V}$ ought be resolved in four diverse computations to find the accurate deviation. All the operations are completed online and updated continuously [27]-[32].

The IncCond method is accomplished by appreciating the sign of $\mathrm{dP} / \mathrm{dV}$, through various sensors: the current and voltage sensor is crafted in order to estimate the PV modules output as appears in Figure 10. The output Volts/Watts is expressed via: 


$$
\begin{aligned}
& \frac{d P}{d V}=0, \operatorname{at}(M P P) \\
& \frac{d P}{d V}>0, \operatorname{left}(M P P) \\
& \frac{d P}{d V}<0, \operatorname{Reight}(M P P) \\
& \frac{d P}{d V}=\frac{d(I)}{d V}=I \times \frac{d V}{d V}=I \times \frac{d V}{d V}+V \times \frac{d I}{d V}=I+V \times \frac{d V}{d I} \\
& \frac{d I}{d V}=-\frac{I}{V}, \operatorname{at}(M P P) \\
& \frac{d I}{d V}>-\frac{I}{V}, \operatorname{left}(M P P) \\
& \frac{d I}{d V}<-\frac{I}{V}, \operatorname{Reight}(M P P)
\end{aligned}
$$

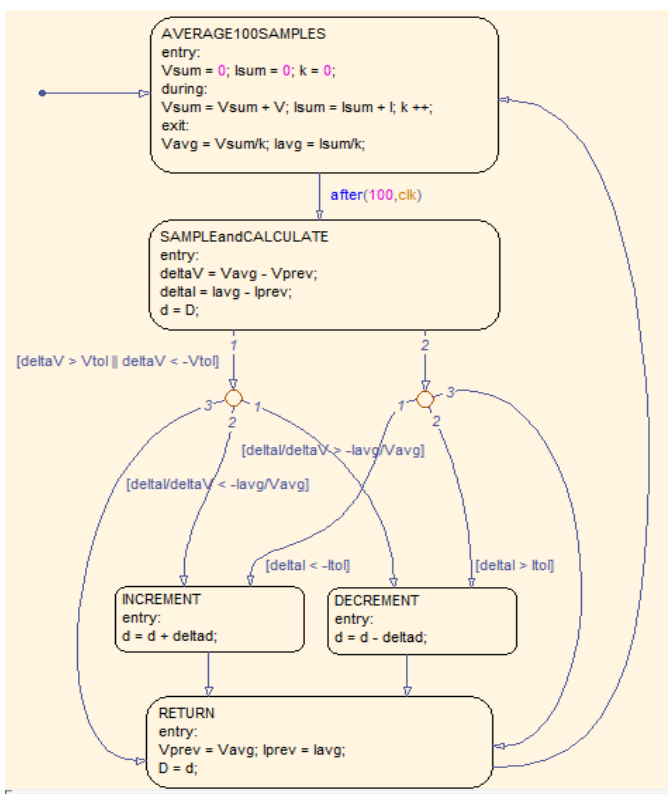

Figure 9. Simulink model of MPPT strategy algorithm for both solar energy and wind conversion system

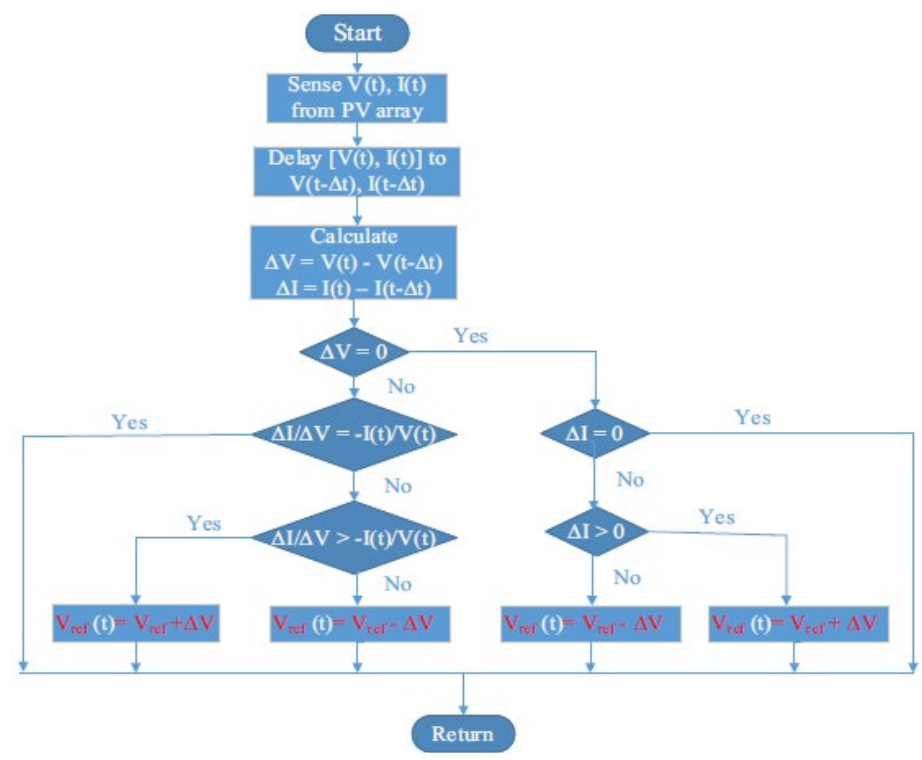

Figure 10. Flowchart of IncCond method 


\section{SIMULATION RESULTS AND DISCUSSION}

\subsection{Performance of solar module}

The simulation model for the proposed power system of solar PV generator, DC/DC converter (Boost), and MPPT, is shown in Figure 11. The current-voltage characteristic of the solar module of $\mathrm{I}_{\mathrm{mpp}}=7.9 \mathrm{~A}, \mathrm{~V}_{\mathrm{mpp}}=32.5 \mathrm{~V}$, and $\mathrm{P}_{\mathrm{mpp}}=255 \mathrm{~W}$, for were gained through a source scale unit. The PVG parameters have been determined and acquired based on connection of 3 panels in series and 8 panels in parallel. The major focus of this work is to utilize both the solar and wind power automatically energize the storage system of stand-alone. It is noted that the energy produced by the solar PV modules is proportionate to the irradiance level and the power-voltage curve of the solar panel under various irradiance levels of the studied site as shown in Figures 12 and 13 respectively.

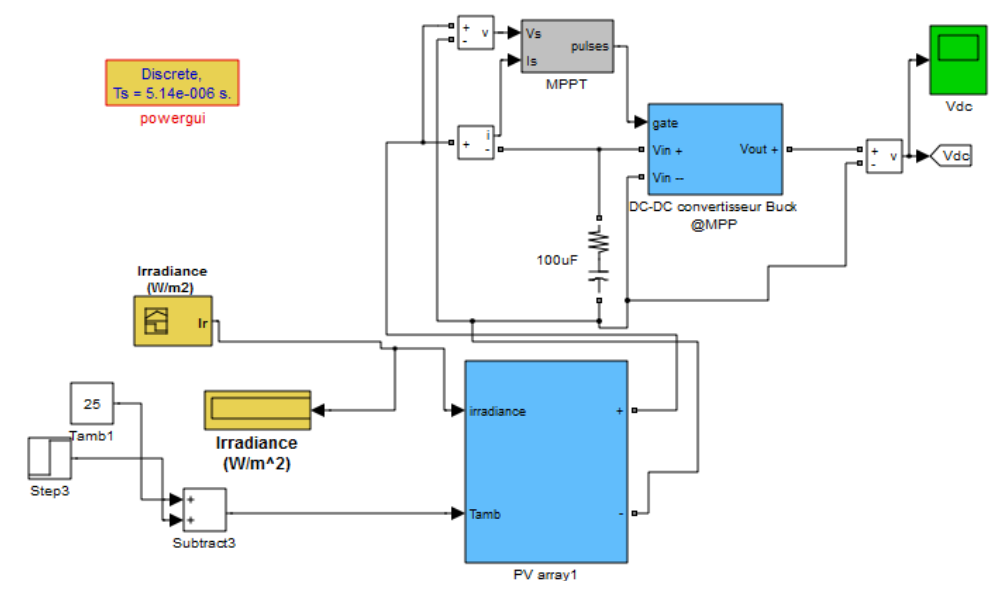

Figure 11. Simulink model of the proposed power system of solar PV generator, DC/DC converter (Boost), and MPPT

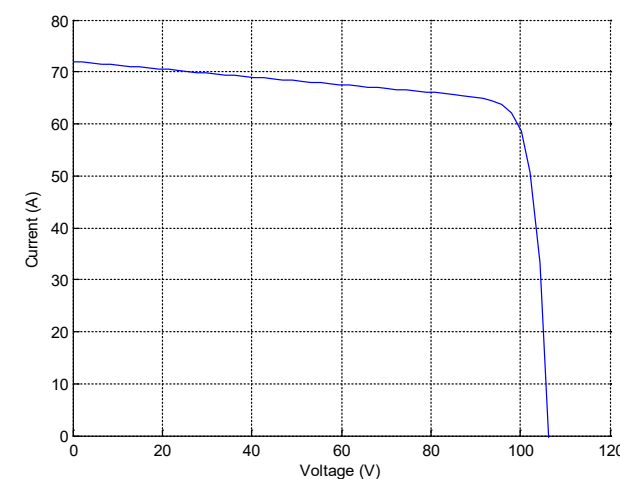

Figure 12. I-V characteristics of solar generator PV of $6 \mathrm{~kW}$

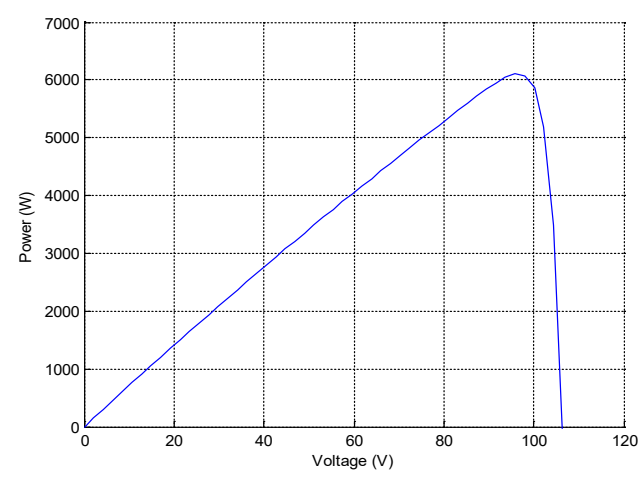

Figure 13. P-V characteristics of solar generator PV of $6 \mathrm{~kW}$

\subsection{Performance of wind turbine}

The simulation model for the proposed power wind turbine, Boost, MPPT system, is present in Figure 14. Figure 15 presents the power produced through the WT renewable sources at different of hours in the day. The energy generated from the wind generator (when the usage rises) is more considerable than the energy produced from the total PV modules. Figure 16 exhibits the required hourly load and its total produced energy for both (WT and PV) renewable sources. In many cases the total estimated of WT and PV modules generate electricity more even when the stand alone usage does not more requested. The power storage process will charge the battery in all situations as when the usages requested more power or not requested via means of its generating modes. It is known that both the speed and produced energy of the hybrid system is proportional to all other. The percentage of efficiency of our proposed hybrid configuration (WT-PV) for different solar irradiance, wind speed, and performance scenario of all system power to cover all order load conditions is shown in Figure 17. The proposed model performance is thoughtful for various loads like $16 \mathrm{~kW}$ generated by the wind turbine system and $6 \mathrm{~kW}$ produced by PV modules, is being applied

Artistic feasibility research on a standalone hybrid solar/wind system based on ... (Oumelkhier Bouchiba) 
to uneven data on wind speed and solar irradiance for site study. The WT and solar panels are put to use their effector functions. The solar battery size relies on the equipment configuration, the battery size is same with load request $(22 \mathrm{~kW})$.

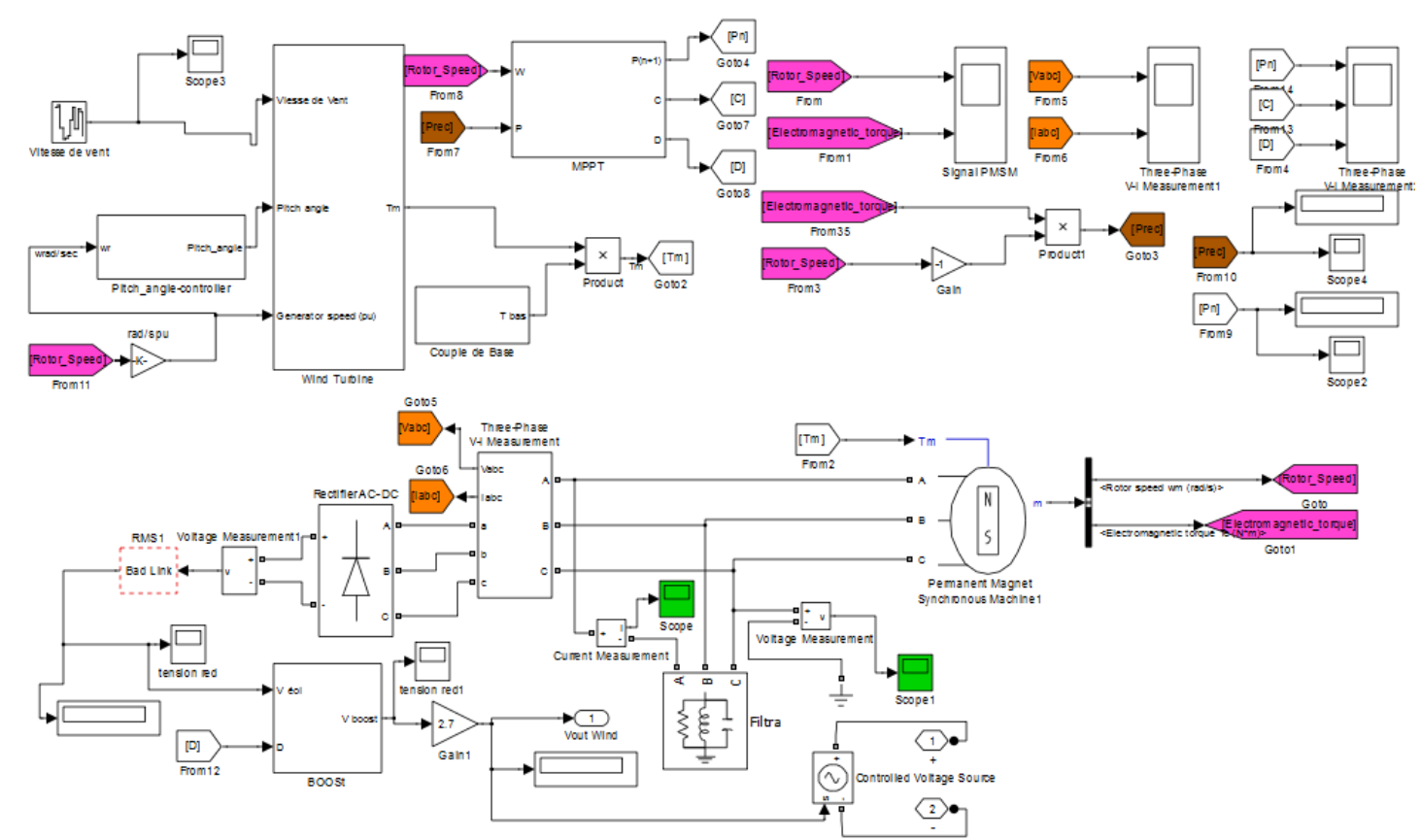

Figure 14. Simulink model of the proposed power wind turbine, Boost, MPPT system

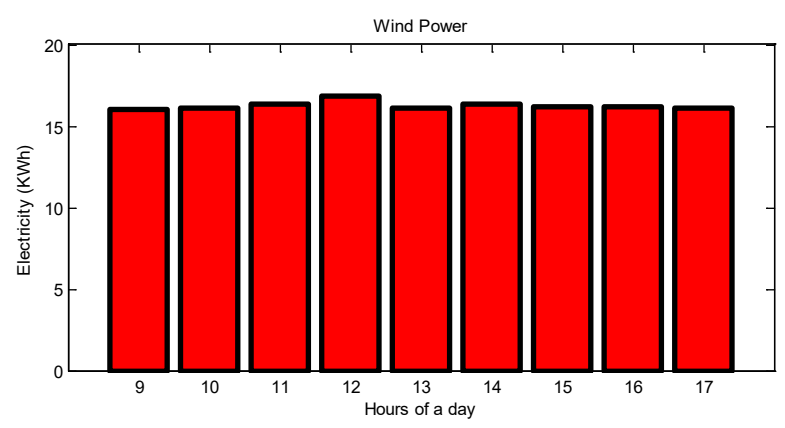

Figure 15. Total energy created via WT system

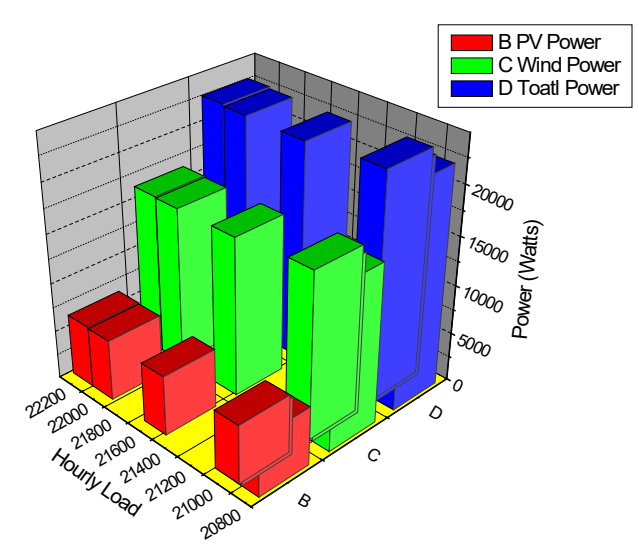

Figure 16. Hourly load versus generated electricity by the proposed hybrid system

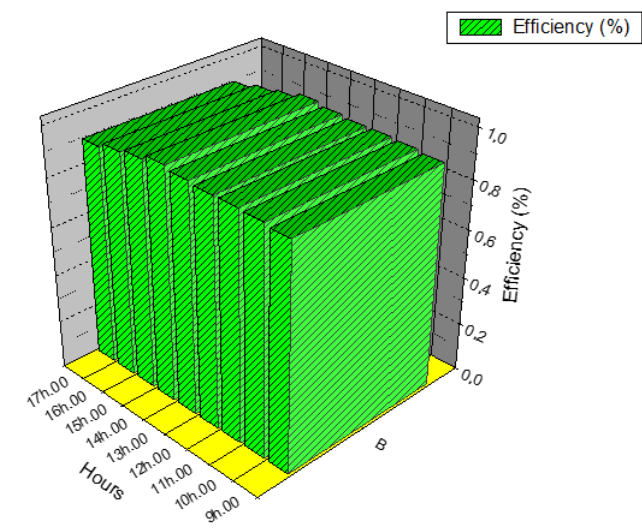

Figure 17. Percentage of efficiency for different hours in day using MPPT in hybrid system 


\section{CONCLUSION}

Renewable power leads to everlasting power produced from the natural sources that does not leave a poor effect on the medium. In this paper, we examine different statistical aspects of developing the sitespecific power generated by a hybrid PV/WT system in several possible arrangements of stand-alone home grids have been carried out. The hourly produced electricity through a day among 9 A.M to 17 P.M is taken in the latitude and longitude of $32^{\circ} 55^{\prime} 29.39^{\prime \prime} \mathrm{N} 3^{\circ} 18^{\prime} 24.60^{\prime \prime}$ E. The studied components are module PV they are equipped for the MPPT to grant the top energy every period, WT, and battery power storage. The achievement of the PV module is confirmed for various irradiance and temperature level. Here, the configurations are developed and founded on the smart components used. Solar battery sizing of the suggested configuration is prepared to supply the load demand of $22 \mathrm{~kW}$ wanting any generating exporter for an up to $9 \mathrm{~h}$. As, DC output energy would be thoughtful in accordance with the measurements. The observer will charge the battery jointly in all the conditions as operation or non-operation.

\section{REFERENCES}

[1] O. Bouchiba, T. Merizgui, B. Gaoui, S. Chettih, and A. Cheknane, "Design and analysis of maximum power point tracking algorithms for PV/Wind hybrid system,” Revista Română de Informatică și Automatică, vol. 30, no. 2, pp. 41-52, 2020, doi: 10.33436/v30i2y202004

[2] M. Tao, Y. Hongxing, L. Lin, P. Jinqing, "Technical feasibility study on a standalone hybrid solar-wind system with pumped hydro storage for a remote island in Hong Kong," Renewable energy, vol. 69, pp. 7-15, 2014, doi: 10.1016/j.renene.2014.03.028.

[3] S. Yashwant, S. C. Gupta, K. B. Aashish, "PV-wind hybrid system: A review with case study," Cogent Engineering, vol. 3, no 1, 2016, Art. no. 1189305, doi: 10.1080/23311916.2016.1189305.

[4] E. L. V. Eriksson, E. Mac A. Gray, "Optimization and integration of hybrid renewable energy hydrogen fuel cell energy systems-A critical review,” Applied energy, vol. 202, pp. 348-364, 2017, doi: 10.1016/j.apenergy.2017.03.132.

[5] C. Anurag and R. P. Saini, "Renewable energy based off-grid rural electrification in Uttarakhand state of India: Technology options, modelling method, barriers and recommendations," Renewable and Sustainable Energy Reviews, vol. 51, pp. 662-681, 2015, doi: 10.1016/j.rser.2015.06.043.

[6] L. Mohammed, S. Tomonobu, F. Mohammed, A. A.-Fattah, L. Lei, and D. Monoj, "Hybrid genetic algorithm fuzzy-based control schemes for small power system with high-penetration wind farms," Applied Sciences, vol. 8, no. 3, 2018, Art. no. 373, doi: 10.3390/app8030373.

[7] K. Vikas, N. Savita, and B. Prashant. "Solar-wind hybrid renewable energy system: A review," Renewable and Sustainable Energy Reviews, vol. 58, pp. 23-33, 2016, doi: 10.1016/j.rser.2015.12.223.

[8] C. Voyant et al., "Machine learning methods for solar radiation forecasting: A review," Renewable Energy, vol. 105, pp. 569-582, 2017, doi: 10.1016/j.renene.2016.12.095.

[9] K. G. Sheela and S. N. Deepa, "Neural network based hybrid computing model for wind speed prediction," Neurocomputing, vol. 122, pp. 425-429, 2013, doi: 10.1016/j.neucom.2013.06.008.

[10] A. J. Sangster, "Concentrated Solar Power, Electromagnetic Foundations of Solar Radiation Collection," Green Energy and Technology, vol. 194, pp. 173-206, 2014.

[11] P. Lauret, V. Cyril, S. Ted, D. Mathieu and P. Philippe, "A benchmarking of machine learning techniques for solar radiation forecasting in an insular context," Solar Energy, vol. 112, pp. 446-457, 2015, doi: $10.1016 /$ j.solener.2014.12.014.

[12] A. E. Duran, G. J. A. Gomez, M. S. de Cardona and M. J. M. Andujar, "Measuring the I-V curve of PV generators," IEEE Industrial Electronics Magazine, vol. 3, no. 3, pp. 4-14, 2009, doi: 10.1109/MIE.2009.933882.

[13] V. V. R. Scarpa, S. Buso and G. Spiazzi, "Low-complexity MPPT technique exploiting the PV module MPP locus characterization," IEEE Transactions on Industrial Electronics, vol. 56, no. 5, pp. 1531-1538, 2009, doi: 10.1109/TIE.2008.2009618.

[14] A. D. Martin and J. R. Vazquez, “MPPT Algorithms Comparison in PV Systems P\&O, PI, Neuro-fuzzy and Back Stepping Controls,” 2015 IEEE International Conference on Industrial Technology (ICIT), 2015, pp. 2841-2847, doi: 10.1109/ICIT.2015.7125517.

[15] E. Trishan and P. L. Chapman, "Comparison of photovoltaic array maximum power point tracking technique," IEEE Transactions on Energy Conversion, vol. 22, no. 2, pp. 439-449, 2007, doi: 10.1109/TEC.2006.874230.

[16] R. Hegazy and A. M. Eltamaly, "A comprehensive comparison of different MPPT techniques for photovoltaic systems," Solar Energy, vol. 112, pp. 1-11, doi: 10.1016/j.solener.2014.11.010.

[17] B. V. Ioan, B. Razvan and I. Marcel, "Comparative analysis of the perturb-and observe and incremental conductance MPPT methods," 8th International Symposium on Advanced Topics in Electrical Engineering, Bucharest, Romania, vol. 2, 2013, pp. 1-4, doi: 10.1109/ATEE.2013.6563483.

[18] H. Hamed, S. Jens and B. Jörg, "Reduced shading effect on half-cell modules-Measurement and simulation," 31th European Photovoltaic Solar Energy Conference and Exhibition, 2015, pp. 2529-2533.

[19] A. Omid and Y. Amirnaser, "A strategy for real power control in a direct-drive PMSG-based wind energy conversion system," IEEE transactions on Power Delivery, vol. 28, no 3, pp. 1297-1305, 2013, doi: 10.1109/TPWRD.2013.2258177.

[20] M. F. Pedro García, T. A. Mark, P. J. María Pinar and P. Mayorkinos, "Condition monitoring of wind turbines: Techniques and methods," Renewable Energy, vol. 46, pp. 169-178, 2012, doi: 10.1016/j.renene.2012.03.003. 
[21] S. A. Mohamed, "Multi-input rectifier stage for a system of hybrid PV/wind driven PMSG," SN Applied Sciences, vol. 1, no 12, 2019, Art. no. 1578, doi: 10.1007/s42452-019-1629-3.

[22] B. Challa and P. Ponnambalam, "The role of thermoelectric generators in the hybrid PV/T systems: A review," Energy conversion and management, vol. 151, pp. 368-385, 2017, doi: 10.1016/j.enconman.2017.08.060.

[23] G. Saumya, M. Ankit and B. Paurush, "Prototype of household inverter using dual-axis solar tracker to overcome shortage of energy," 2016 International Conference on Information Technology (InCITe) - The Next Generation IT Summit on the Theme - Internet of Things: Connect your Worlds, 2016. pp. 160-165, doi: 10.1109/INCITE.2016.7857609.

[24] R. K. Akikur, R. Saidur, H. W. Ping and K. R. Ullah, "Comparative study of stand-alone and hybrid solar energy systems suitable for off-grid rural electrification: A review," Renewable and Sustainable Energy Reviews, vol. 27, pp. 738-752, 2013, doi: 10.1016/j.rser.2013.06.043.

[25] K. M. Waseem, W. Jie, M. Meiling, X. Linyun, P. Li and F. Wu, "Optimal energy management and control aspects of distributed microgrid using multi-agent systems," Sustainable Cities and Society, vol. 44, pp. 855-870, 2019, doi: 10.1016/j.scs.2018.11.009.

[26] Q. Zheng, P. Yan, Z. Hamidreza and C. Niya, "A review and discussion of decomposition-based hybrid models for wind energy forecasting applications,” Applied Energy, vol. 235, pp. 939-953, 2019, doi: 10.1016/j.apenergy.2018.10.080.

[27] C. Yaow-Ming, L. Yuan-Chuan, H. Shih-Chieh and C. Chung-Sheng, "Multi-input inverter for grid-connected hybrid PV/wind power system," IEEE transactions on power electronics, vol. 22, no 3, pp. 1070-1077, 2007, doi: 10.1109/TPEL.2007.897117.

[28] O. N. Angela, L. Marco, M. Rosa and A. Dell'Aquila, "A survey of control issues in PMSG-based small windturbine systems," IEEE transactions on Industrial Informatics, vol. 9, no 3, pp. 1211-1221, 2013, doi: 10.1109/TII.2013.2272888.

[29] L. Xiong, W. Peng and L. Poh Chiang, "A hybrid AC/DC microgrid and its coordination control," IEEE Transactions on smart grid, vol. 2, no 2, pp. 278-286, 2011, doi: 10.1109/TSG.2011.2116162.

[30] B. Sungwoo and K. Alexis, "Dynamic modeling and operation strategy for a microgrid with wind and photovoltaic resources," IEEE Transactions on smart grid, vol. 3, no 4, pp. 1867-1876, 2012, doi: 10.1109/TSG.2012.2198498.

[31] S. Sumathi, L. A. Kumar and P. Surekha, "Wind Energy Conversion Systems," Solar PV and Wind Energy Conversion Systems, 2015. pp. 247-307.

[32] E. Ahmad, "Utility integration of PV-wind-fuel cell hybrid distributed generation systems under variable load demands," International Journal of Electrical Power \& Energy Systems, vol. 62, pp. 689-699, 2014, doi: 10.1016/j.ijepes.2014.05.020. 